\title{
BONDING PERFORMANCE OF STRUCTURAL ADHESIVES ON HEAT-TREATED MIMOSA SCABRELLA AND PINUS OOCARPA WOOD
}

\author{
AMÉLIA GUIMARÃES CARVALHO, ${ }^{*}$ BRUNO GEIKE DE ANDRADE, ${ }^{* *}$ \\ DANILO BARROS DONATO, ${ }^{* *}$ CARLOS MIGUEL SIMÕES DA SILVA, ${ }^{* *}$ ANGÉLICA DE CASSIA \\ OLIVEIRA CARNEIRO, ${ }^{* *}$ VINÍCIUS RESENDE DE CASTRO ${ }^{* *}$ and \\ ANTÔNIO JOSÉ VINHA ZANUNCIO* \\ "Universidade Federal de Uberlândia, Instituto de Ciências Agrárias, Monte Carmelo, \\ MG, 38500-000, Brasil \\ ** Universidade Federal de Viçosa, Viçosa, MG, 36570-900, Brasil \\ \Corresponding author: A. J. Vinha Zanuncio,ajvzanuncio@ufu.br
}

Received March 30, 2020

\begin{abstract}
Wood adhesives are used to develop various products from wood species, such as Mimosa scabrella and Pinus oocarpa. The variety of adhesives, wood species and treatments make it difficult to find the best combination for use. The objective of this study was to evaluate the performance of structural adhesives on M. scabrella and P. oocarpa wood. Wood samples were heat treated in nitrogen atmosphere at 180,200 and $220{ }^{\circ} \mathrm{C}$ for one hour. The mass loss upon heat treatment, equilibrium moisture content and chemical composition of the wood were evaluated. The wood was bonded with polyurethane/E23, resorcinol formaldehyde and polyvinyl acetate (PVA) adhesives, with the application of $12 \mathrm{kgf} . \mathrm{cm}^{-2}$ and grammage of $200 \mathrm{~g} \cdot \mathrm{m}^{-2}$. Heat treatment reduced mass, equilibrium moisture and holocellulose content, and increased the lignin and extractives contents of $M$. scabrella and P. oocarpa. The heat treatment also decreased the shear strength and increased the percentage of wood failure with the adhesives evaluated. The shear strength and failure percentage achieved with resorcinol were better and thus this adhesive is the most appropriate one for heat-treated wood bonding.
\end{abstract}

Keywords: equilibrium moisture content, resorcinol formaldehyde, shear, wood chemistry

\section{INTRODUCTION}

Mimosa scabrella and Pinus oocarpa are used for the production of lumber, furniture and structural elements, but some of their characteristics, such as hygroscopicity and biodegradability, ${ }^{1,2}$ may limit some of the uses. Heat treatment can reduce these problems by improving the wood dimensional stability ${ }^{3,45}$ and biological resistance. ${ }^{6}$ However, this process also decreases the mechanical resistance of the material, causing inconveniences during its use. ${ }^{6}$

Previous research reported on heat treatment ranging from 180 to $280{ }^{\circ} \mathrm{C}$ between 15 minutes and 24 hours $^{7}$ according to species, sample size and required wood quality. ${ }^{8,9}$ The use of an inert environment gas, such as nitrogen, can prevent or minimize oxidative processes and, consequently, damage to wood during the thermal process. ${ }^{10}$ This process degrades hemicelluloses and reduces hydrophilic groups. ${ }^{3,11}$ This inactivates the surface, ${ }^{12}$ modifies wettability ${ }^{13,14}$ and reduces liquid penetration, ${ }^{15}$ as structural adhesives in wood.

Changes in wood due to heat treatment can alter its interaction with adhesives, the reduction of $\mathrm{pH}$ due to the application of heat can alter the quality of the adhesive cure. ${ }^{16}$ There are different types of adhesives that can be applied to wood. Resorcinol-formaldehyde adhesives have been employed since 1943 to manufacture marine plywood and structural parts for use in harsh environments. ${ }^{17}$ The high cost of resorcinol ${ }^{18}$ has led to the search for other adhesives, such as polyurethane, without formaldehyde, intended for use in solid wood. ${ }^{19}$

Other adhesives based on polyvinyl acetate (PVA) are used in the furniture and/or logging industry for internal use, and available as a solution or emulsion. ${ }^{20}$ The main advantages of this adhesive are its curing time at $10{ }^{\circ} \mathrm{C}$, resistance to inorganic influences, simple 
application and no release of harmful substances, besides being cheaper than other commercial adhesives. $^{21,22}$

Different wood species, heat treatment temperatures and adhesives allow creating different combinations, requiring studies to choose the best option. The objective of this work was to evaluate the quality of heat-treated Mimosa scabrella and Pinus oocarpa wood bonded with commercial adhesives.

\section{EXPERIMENTAL}

\section{Biological material and heat treatment}

Mimosa scabrella Bentham and Pinus oocarpa Schiede wood samples were oven dried with air circulation at $70{ }^{\circ} \mathrm{C}$ to reach $3 \%$ moisture content (dry basis) and sawn in $30 \times 5 \times 2 \mathrm{~cm}$ samples (length, width and thickness, respectively).

These samples were fixed between iron supports to avoid warping and placed in the oven for one hour at the established treatment temperature $(180,200$ and $220{ }^{\circ} \mathrm{C}$ ), avoiding contact of their sides with the bottom. The air was removed to form vacuum and nitrogen was applied at $0.6 \mathrm{kgf} \mathrm{cm}^{-2}$ before starting the experiment.

\section{Characterization of adhesives}

Viscosity, $\mathrm{pH}$ and solids content were determined in the resorcinol-formaldehyde and polyvinyl acetate (PVA) adhesives. In addition, the working time after catalyst addition (20\% paraformaldehyde) was determined for the resorcinol formaldehyde adhesive.

\section{Physical and chemical analysis of wood}

The mass loss during the heat treatment was calculated with Equation (1):

$$
M L=\left[\left(M_{1}-M_{2}\right) / M_{1}\right] \times 100
$$

where $\mathrm{ML}=$ mass loss $(\%) ; \mathrm{M}_{1}=$ dry wood mass; $\mathrm{M}_{2}$ = wood mass after heat treatment.

After the heat treatment, the wood was acclimatized at $23{ }^{\circ} \mathrm{C}$ and $65 \%$ relative humidity, and the equilibrium moisture content (EMC) was obtained after stabilization according to ABNT NBR7190. ${ }^{23}$ The wood samples were processed in a Wiley mill to obtain sawdust. The samples were ground and sieved on a 40mesh to 60-mesh screen to determine the structural chemical composition according to TAPPI standards. The wood was prepared for chemical testing according to TAPPI T264. ${ }^{24}$ The extractives, lignin, cellulose and hemicelluloses contents were determined according to TAPPI T204 om- $88,{ }^{25}$ TAPPI T222 om- $98,{ }^{26}$ and TAPPI T223 om- $84,{ }^{24}$ respectively.

\section{Mechanical strength test}

Control and heat-treated wood samples were glued in a press under $12 \mathrm{kgf} \mathrm{cm}^{-2}$ pressure. The grammage used was $200 \mathrm{~g} \mathrm{~m}^{-2}$ (single line) and the joints remained in the press for 24 hours. Three wood joints were bonded by the treatment.

The samples were adapted and tested according to the standard ABNT NBR $7190 .{ }^{23}$ Four samples were obtained from each wood joint, totaling 12 per treatment. Shear strength was determined on a universal testing machine.

\section{Statistical analysis}

Homogeneity of variance (Bartlett's test at 5\% significance) and normality tests were performed (Shapiro-Wilk test at 5\% significance). The means obtained were analyzed by Tukey's test at 5\% probability.

\section{RESULTS AND DISCUSSION}

The viscosity of the PVA and polyurethane/E23 adhesive was higher and lower, respectively (Table 1), this parameter is directly proportional to the degree of polymerization of the adhesive. The high viscosity makes it difficult to evenly distribute the adhesive over the wood, reducing its penetration into the structure, impairing wetting and possibly causing a thick glue line. ${ }^{18}$ Wood penetration and absorption are higher for low viscosity adhesives, but in extreme situations, this results in a scarce glue line or excessive wood absorption.

The addition of the catalyst (paraformaldehyde) increased the polymerization and viscosity of the resorcinol adhesive, with six hours working time. The time for the catalyst reaction starts with its addition to resorcinol and lasts until the adhesive reaches maximum viscosity to bond the parts.

The increase in polymerization and viscosity in the case of the resorcinol adhesive is due to the increase in the solids content, with higher values than in the case of PVA. This confirms the fact that the solids content improves the quality of the glue line and, consequently, the adhesion between the wood and the adhesive. ${ }^{27}$ The $\mathrm{pH}$ of the adhesives ranged from 4.16 to 6.94 , which are adequate values, considering that the adhesive $\mathrm{pH}$ should be between 2.5 and 11 to avoid wood fiber degradation. ${ }^{28}$

The heat treatment reduced the mass, equilibrium moisture content (EMC) and holocellulose content, while increasing the extractives and lignin contents (Table 2).

The wood mass loss of Pinus oocarpa and $M$. scabrella was higher from 220 and $200{ }^{\circ} \mathrm{C}$, respectively, with higher values for the latter species, showing that the wood quality also influences the heat treatment. 
The greater resistance to thermal degradation of softwoods is due to their lower density, making it difficult to conduct heat. ${ }^{29}$ In addition, hardwoods are richer in xylan, which releases acetic acid with heat and maximizes the degradation of hemicelluloses and of the cellulose amorphous region. ${ }^{7,30}$ The resistance of softwoods to high temperatures was reported for Pinus caribaea, with $9.6 \%$ mass loss, compared to Eucalyptus saligna, with $8.7 \%$ loss, both treated at $180{ }^{\circ} \mathrm{C}^{31}$

The heat treatment altered the wood structural chemistry (Table 2). Holocellulose is the main wood chemical component degraded by the heat treatment, with a reduction from 65.94 and 72.96 to 60.31 and $70.28 \%$, for $P$. oocarpa and $M$. scabrella wood at $220{ }^{\circ} \mathrm{C}$, respectively. This compound is the sum of cellulose and hemicelluloses contents, the latter having an amorphous structure and low polymerization degree, and beginning to degrade between 180 to $200{ }^{\circ} \mathrm{C},{ }^{32,33}$ reducing its content.

The lignin content in the heat-treated $P$. oocarpa and M. scabrella wood increased by 13.9 and $4.5 \%$, respectively, at $220{ }^{\circ} \mathrm{C}$. Lignin degradation begins at $160{ }^{\circ} \mathrm{C}$, but it is slower than that of cellulose and hemicelluloses, and therefore, lignin traces can be found at $900{ }^{\circ} \mathrm{C} .{ }^{34}$ Lignin is the most thermally stable chemical compound in the cell wall, ${ }^{29}$ justifying its increase in wood under heat treatment.

The total extractives content increased in $P$. oocarpa and M. scabrella woods from $200^{\circ} \mathrm{C}$ and $180{ }^{\circ} \mathrm{C}$, respectively. The heat treatment process volatilizes a part of the extractives, ${ }^{33}$ but the degradation of hemicelluloses generates compounds that remain in the biomass as molecules with weak fiber bonds. ${ }^{29}$ The alcohol/toluene removes these compounds, increasing the extractives content ${ }^{31,35}$ and masking the real value of those present in wood. ${ }^{36}$

The heat treatment reduced the equilibrium moisture content (EMC) of $P$. oocarpa wood from $180{ }^{\circ} \mathrm{C}$, reaching lower values at $220{ }^{\circ} \mathrm{C}$, while for $M$. scabrella, this parameter was lower in the wood treated at $180{ }^{\circ} \mathrm{C}$, with similar values at higher temperatures. This reduction is due to the depolymerization of hemicelluloses into oligomeric and monomeric units and, being dehydrated to aldehydes due to acidic conditions, reducing the amount of hydroxyl groups. ${ }^{37}$

Table 1

Adhesive, solid content (Solid), viscosity (cP), $\mathrm{pH}$ and working time (h) of adhesives used for Mimosa scabrella and Pinus oocarpa wood

\begin{tabular}{lcccc}
\hline Adhesive & Solid (\%) & Viscosity $(\mathrm{cP})$ & $\mathrm{pH}$ & Working time (h) \\
\hline PVA & 45.6 & 13650 & 4.16 & - \\
Polyurethane/E23 & - & $1800^{*}$ & - & - \\
Resorcinol with catalyst & 68.2 & 4740 & 6.76 & 6 \\
Resorcinol without catalyst & 61.7 & 1827 & 6.94 & - \\
\hline
\end{tabular}

*Provided by the manufacturer

Table 2

Mass loss (ML), total extractives (TE), total lignin (TL), holocellulose (HO) and equilibrium moisture content (EMC) of heat-treated Mimosa scabrella and Pinus oocarpa woods

\begin{tabular}{lcccccc}
\hline Species & Temperature & ML $(\%)$ & TE (\%) & TL (\%) & HO (\%) & EMC (\%) \\
\hline \multirow{3}{*}{ Mimosa } & Control & - & $1.36^{2.0} \mathrm{c}$ & $25.7^{5.1} \mathrm{~b}$ & $72.96^{4.8} \mathrm{a}$ & $13.5^{7.2} \mathrm{a}$ \\
scabrella & $180^{\circ} \mathrm{C}$ & $4.3^{3.3} \mathrm{~b}$ & $2.03^{3.5} \mathrm{~b}$ & $26.2^{4.6} \mathrm{a}$ & $71.78^{5.1} \mathrm{~b}$ & $12.0^{6.5} \mathrm{~b}$ \\
& $200^{\circ} \mathrm{C}$ & $7.0^{3.9} \mathrm{a}$ & $2.04^{4.0} \mathrm{~b}$ & $26.5^{4.2} \mathrm{a}$ & $71.48^{3.6} \mathrm{~b}$ & $11.6^{6.9} \mathrm{~b}$ \\
& $220^{\circ} \mathrm{C}$ & $8.9^{4.2} \mathrm{a}$ & $2.86^{3.8} \mathrm{a}$ & $26.9^{4.3} \mathrm{a}$ & $70.28^{4.7} \mathrm{c}$ & $11.3^{6.4} \mathrm{~b}$ \\
\hline \multirow{3}{*}{ Pinus } & Control & - & $1.82^{3.2} \mathrm{~b}$ & $32.3^{4.7} \mathrm{c}$ & $65.94^{4.5} \mathrm{a}$ & $14.7^{5.6} \mathrm{a}$ \\
oocarpa & $180^{\circ} \mathrm{C}$ & $4.5^{2.3} \mathrm{~b}$ & $1.91^{2.2} \mathrm{~b}$ & $32.7^{4.9} \mathrm{c}$ & $65.40^{4.6} \mathrm{a}$ & $12.7^{7.3} \mathrm{~b}$ \\
& $200^{\circ} \mathrm{C}$ & $4.9^{2.1} \mathrm{~b}$ & $3.50^{4.1} \mathrm{a}$ & $34.2^{3.5} \mathrm{~b}$ & $62.34^{5.3} \mathrm{~b}$ & $12.9^{6.4} \mathrm{~b}$ \\
& $220{ }^{\circ} \mathrm{C}$ & $6.3^{2.8} \mathrm{a}$ & $3.87^{4.5} \mathrm{a}$ & $36.8^{3.8} \mathrm{a}$ & $60.31^{4.2} \mathrm{c}$ & $11.4^{7.0} \mathrm{c}$
\end{tabular}

*Averages with the same letter, per column and species, do not differ by Tukey's test $(\alpha=0.05)$. Values in superscript represent the coefficient of variation 
Table 3

Shear strength (MPa) and wood failure (\%) of bonded joints of heat-treated

Mimosa scabrella and Pinus oocarpa

\begin{tabular}{|c|c|c|c|c|c|c|}
\hline \multirow{2}{*}{ Parameter } & \multirow{2}{*}{ Species } & \multirow{2}{*}{ Adhesive } & \multicolumn{4}{|c|}{ Temperature $\left({ }^{\circ} \mathrm{C}\right)$} \\
\hline & & & Control & 180 & 200 & 220 \\
\hline \multirow{6}{*}{$\begin{array}{l}\text { Shear } \\
\text { strength }\end{array}$} & \multirow{3}{*}{$\begin{array}{c}\text { Mimosa } \\
\text { scabrella }\end{array}$} & Resorcinol & $14.1^{8.3} \mathrm{Aa}$ & $12.7^{11.2} \mathrm{Ba}$ & $13.6^{7.8} \mathrm{Aa}$ & $9.6^{7.8} \mathrm{Ca}$ \\
\hline & & PVA & $7.0^{9.5} \mathrm{Ac}$ & $6.5^{8.6} \mathrm{Bb}$ & $5.5^{6.5} \mathrm{Cc}$ & $4.0^{9.0} \mathrm{Dc}$ \\
\hline & & Polyurethane/E23 & $9.9^{10.1} \mathrm{Ab}$ & $7.2^{8.9} \mathrm{Bb}$ & $7.4^{8.0} \mathrm{Bb}$ & $5.2^{10.6} \mathrm{Cb}$ \\
\hline & \multirow{3}{*}{$\begin{array}{c}\text { Pinus } \\
\text { oocarpa }\end{array}$} & Resorcinol & $7.9^{10.5} \mathrm{Aa}$ & $6.7^{10.8} \mathrm{Ba}$ & $6.2^{11.2} \mathrm{Ba}$ & $5.4^{7.9} \mathrm{Ca}$ \\
\hline & & PVA & $6.1^{10.8} \mathrm{Ab}$ & $5.5^{9.5} \mathrm{Bb}$ & $5.5^{10.6} \mathrm{Bb}$ & $3.5^{6.0} \mathrm{Cb}$ \\
\hline & & Polyurethane/E23 & $8.8^{11.3} \mathrm{Aa}$ & $6.4^{11.6} \mathrm{Ba}$ & $6.3^{9.3} \mathrm{Ba}$ & $6.0^{8.0} \mathrm{Ba}$ \\
\hline \multirow{6}{*}{$\begin{array}{l}\text { Wood } \\
\text { failure }\end{array}$} & \multirow{3}{*}{$\begin{array}{c}\text { Mimosa } \\
\text { scabrella }\end{array}$} & Resorcinol & 85.1 & 78.9 & 70.1 & 70.3 \\
\hline & & PVA & 0 & 0 & 0 & 0 \\
\hline & & Polyurethane/E23 & 5.1 & 3.5 & 1.7 & 2.6 \\
\hline & \multirow{3}{*}{$\begin{array}{c}\text { Pinus } \\
\text { oocarpa }\end{array}$} & Resorcinol & 95.5 & 68.6 & 72.1 & 70.4 \\
\hline & & PVA & 21.7 & 12.2 & 14.7 & 11.7 \\
\hline & & Polyurethane/E23 & 59.5 & 36.8 & 30.9 & 30.7 \\
\hline
\end{tabular}

*Means with the same capital letter per line or lowercase letter per column, per species, do not differ by Tukey's test ( $\alpha$ $=0.05$ ). Values in superscript represent the coefficient of variation

This prevents moisture adsorption onto degraded hydrophilic groups, reducing the equilibrium moisture content, ${ }^{3,38,39}$ as also previously observed in wood subjected to heat treatment, ${ }^{40,41}$ carbonization $^{42}$ and hydrothermal treatment. ${ }^{43}$

The shear strength varied as a function of wood species, type of adhesive and heat treatment temperature (Table 3), but higher values were achieved for M. scabrella without heat treatment in resorcinol bonded joints.

The shear strength of M. scabrella wood was higher when bonded with resorcinol formaldehyde, while the $P$. oocarpa wood showed the best results when bonded with the resorcinol formaldehyde and polyurethane/E23 adhesives. The lower performance of the PVA adhesive is due to its higher viscosity (Table 1), affecting its penetration and making its spread on the wood surface more difficult, compromising mobility, penetration and wetting functions. ${ }^{27} \mathrm{In}$ addition, the lower solids content hinders the formation of the adhesive line after adhesive solidification.

The heat treatment reduced the shear strength of $P$. oocarpa and M. scabrella woods, for all the three adhesives evaluated. The heat treatment decreases the wood-adhesive bonding, modifying the anatomical, physical, mechanical and chemical properties of the wood, affecting the physicochemical phenomena that occur during the adhesion process. ${ }^{7}$ In addition, the wood-adhesive interaction affected the use of adhesives in the heat-treated wood at higher temperatures, which is explained by mechanical, adsorption, diffusion and chemical theories. ${ }^{44,45}$ Holocellulose degradation upon the heat treatment decreases wood hygroscopicity, reducing its wettability to polar adhesives, ${ }^{46,47}$ such as those used in this work. The increase in the extractives content at higher heat treatment temperatures (Table 2) decreased the shear strength. This was caused by the movement of these compounds to the surface and their inactivation on the wood surface, reducing the wood-adhesive bonding. ${ }^{15}$ The reduction in the shear strength of the PVA-bonded wood after the heat treatment is caused by the higher viscosity and lower penetration capacity of this adhesive, with a 42.8 and $42.6 \%$ drop in $P$. oocarpa and M. scabrella woods treated at 220 ${ }^{\circ} \mathrm{C}$, respectively. A reduction in glue line resistance in heat-treated woods was also observed for Pinus brutia and Abies borrissiregis treated at temperatures above $180{ }^{\circ} \mathrm{C}^{48}$ The shear strength values of Quercus and Picea treated at $160{ }^{\circ} \mathrm{C}$ increased by $30 \%$, but these values were lower at 180 and $210{ }^{\circ} \mathrm{C} .{ }^{49}$

The increase in the heat treatment temperature decreased the wood failure percentage (Table 3). High wood failure values indicate adequate bonding quality, because it shows that breakage occurred because of the wood and not of the glue line. Variations in the wood percentage failures accompanied the shear strength. The woodadhesive bond was negatively affected by the reduction of the hygroscopicity, causing glue line failures rather than wood failure, as reported for Populus beijingensis wood. ${ }^{47}$ The combination of 
Mimosa scabrella with the PVA adhesive (low solids and high viscosity) showed the worst results, with $0 \%$ wood failure. The resorcinol adhesive was the only one that achieved a minimum wood failure percentage of $60 \%$, as stipulated by ASTM $3110^{50}$

\section{CONCLUSION}

The viscosity of the PVA adhesive was higher than that of the polyurethane/E23. Upon the heat treatment, the mass loss was higher for $M$. scabrella wood. This process increased the extractives and lignin content, while decreasing the holocellulose and reducing the wood equilibrium moisture content. The shear strength varied as a function of species, adhesive type and heat treatment intensity, with higher values for $M$. scabrella without heat treatment and bonded with resorcinol, and lower for P. oocarpa, heat-treated at $220^{\circ} \mathrm{C}$ and glued with PVA. Wood failure was greater in the wood bonded with resorcinol. Moreover, this adhesive was the only one that met the ASTM 3110 requirements (1995).

ACKNOWLEDGMENT: We are grateful to "Conselho Nacional de Desenvolvimento Científico e Tecnológico (CNPq), Coordenação de Aperfeiçoamento de Pessoal de Nível Superior (CAPES - Finance Code 001) and Fundação de Amparo à Pesquisa do Estado de Minas Gerais (FAPEMIG)" for financial support. Momentive Química do Brasil LTDA and Bayer Material Science AG furnished the resorcinol formaldehyde and the polyurethane/E23 adhesives.

\section{REFERENCES}

1 R. D. E. A. Delucis, R. H. Diaz, S. C. Amico, J. Labidi and D. A. Gatto, Cellulose Chem. Technol., 51, 889 http://www.cellulosechemtechnol.ro/pdf/CCT910(2017)/p.889-898.pdf

2 R. D. E. A. Delucis, R. Beltrame and D. A. Gatto, Cellulose Chem. Technol., 53, 635 (2019), https://doi.org/10.35812/CelluloseChemTechnol.2019. 53.62

3 A. J. V. Z. Zanuncio, J. P. Motta, T. A. Silveira, E. S. Farias and P. Trugilho, BioResources, 9, 293 (2014), https://ojs.cnr.ncsu.edu/index.php/BioRes/article/view/ BioRes_09_1_293_Zanuncio_Colorimetric_Eucalyptu

4 S. L. Oliveira, T. P. Freire, L. M. Mendes and R. F. Mendes, Mater. Res., 20, 183 (2017), http://www.scielo.br/scielo.php?script=sci_arttext\&pid $=$ S1516-14392017000100183
5 X. Wang, A. Chen, X. Xie, Y. Wu, L. Zhao et al., Holzforschung, 72, 1063 (2017), https://www.researchgate.net/publication/326357667_ Effects_of_thermal_modification_on_the_physical_ch emical_and_micromechanical_properties_of_Masson_ pine_wood_Pinus_massoniana_Lamb

J. Wehsener, C. Brischke, L. Meyer-Veltrup, J. Hartig and P. Haller, Eur. J. Wood Wood Prod., 76, 809 (2018), http://dx.doi.org/10.1007/s00107-0171278-4

7 B. M. Esteves and H. M. Pereira, BioResources, 4, 370

(2009),

https://ojs.cnr.ncsu.edu/index.php/BioRes/article/view/ BioRes_04_1_\%23\%23\%23\%23_Esteves_P_Wood_ Mod_Heat_Treatment

8 S. Korkut, Ind. Crop. Prod., 36, 355 (2012), https://www.sciencedirect.com/science/article/abs/pii/S 0926669011003943

9 T. Li, D. Cheng, S. Avramidis, M. E. P. Wålinder and D. Zhou, Constr. Build. Mater., 144, 671 (2017), http://dx.doi.org/10.1016/j.conbuildmat.2017.03.218

10 T. Joščák, M. Mamoňová, M. Babiak, A. Teischinger and U. Müller, Holz als Roh., 65, 285 (2007),

https://link.springer.com/article/10.1007/s00107-0060162-4

11 J. J. Weiland and R. Guyonnet, Holz als Roh., 61, 216

(2003), https://link.springer.com/article/10.1007/s00107-0030364-y

12 J. Follrich, U. Müller and W. Gindl, Holz als Roh., 64, 373

(2006), https://link.springer.com/article/10.1007/s00107-0060107-y

13 B. F. Balkis, S. Hiziroglu and Md. P. Tahir, Mater. Des., $\quad$ 43, $348 \quad$ (2013), http://dx.doi.org/10.1016/j.matdes.2012.06.054

14 T. T. Nguyen, X. Ji, T. H. Van Nguyen and M. Guo, Holzforschung, 72, $37 \quad$ (2017), https://doi.org/10.1515/hf-2017-0004

15 M. Sernek, M. Boonstra, A. Pizzi, A. Despres and P. Gérardin, Holz als Roh., 66, 173 (2008), https://doi.org/10.1007/s00107-007-0218-0

16 S. Poncsák, S. Q. Shi, D. Kocaefe and G. Miller, J. Adhes. Sci. Technol., 21, $745 \quad$ (2007), https://doi.org/10.1163/156856107781362653

17 E. M. Alamsyah, M. Yamada and K. Taki, J. Wood Sci., 54, 208 (2008), https://doi.org/10.1007/s10086007-0945-1

18 P. Li, Y. Wu, Y. Zhou and Y. Zuo, Int. J. Biol. Macromol., $\quad 127, \quad 12 \quad$ (2019), https://doi.org/10.1016/j.ijbiomac.2018.12.249

19 S. Bockel, I. Mayer, J. Konnerth, S. Harling, P. Niemz et al., Int. J. Adhes. Adhes., 91, 43 (2019), https://doi.org/10.1016/j.ijadhadh.2019.03.001

20 J. C. Biazzon, M. P. Lima, R. A. Munis, V. A. De Araujo, E. A. M. Morales et al., BioResources, 14, 4590

(2019), https://doi.org/10.15376/biores.14.2.4590-4602 
21 J. Bomba, J. Cvach, P. Šedivka and M. Kvietková, BioResources, $\quad 9, \quad 1027 \quad$ (2014), https://bioresources.cnr.ncsu.edu/resources/strengthincrease-pattern-in-joints-bonded-with-pvac-adhesives/ 22 A. Salvini, L. M. Saija, M. Lugli, G. Cipriani and C. Giannelli, J. Adhes. Sci. Technol., 24, 317 (2011), https://doi.org/10.1163/016942410X507731

23 Associação Brasileira de Normas Técnicas, NBR7190 (1997)

24 TAPPI Technical Association of the Pulp and Paper, TAPPI T 264 cm-97 (1997)

25 TAPPI Technical Association of the Pulp and Paper Industry, TAPPI t-T 204 om-88 (1988)

26 TAPPI Technical Association of the Pulp and Paper Industry, TAPPI T222 om-98 (1998)

27 F. A. Kamke and J. N. Lee, Wood Fiber Sci., 39, 205

https://wfs.swst.org/index.php/wfs/article/view/641/64 1

28 F. Stoeckel, J. Konnerth and W. Gindl-Altmutter, Int. J. Adhes. Adhes., 45, 32 (2013), http://dx.doi.org/10.1016/j.ijadhadh.2013.03.013

${ }^{29}$ K. Candelier, M. F. Thevenon, A. Petrissans, S. Dumarcay, P. Gerardin et al., Ann. For. Sci., 73, 571 (2016), http://dx.doi.org/10.1007/s13595-016-0541-x

30 M. Chaouch, M. Pétrissans, A. Pétrissans and P. Gérardin, Polym. Degrad. Stabil., 95, 2255 (2010), http://dx.doi.org/10.1016/j.polymdegradstab.2010.09.0 10

31 J. O. Brito, F. G. Silva, M. M. Leão and G. Almeida, Bioresour. Technol., 99, 8545 (2008), https://www.ncbi.nlm.nih.gov/pubmed/18586488

32 T. Sebio-Puñal, S. Naya, J. López-Beceiro, J. Tarrío-Saavedra and R. Artiaga, J. Therm. Anal. Calorim., $\quad 109, \quad 1163 \quad$ (2012), https://doi.org/10.1007/s10973-011-2133-1

33 M. Mecca, M. D'Auria and L. Todaro, Wood Sci. Technol., $\quad 53, \quad 119 \quad$ (2019), https://doi.org/10.1007/s00226-018-1057-3

34 H. Yang, R. Yan, H. Chen, D. H. Lee and C. Zheng, Fuel, 86, $1781 \quad$ (2007), https://doi.org/10.1016/j.fuel.2006.12.013

35 B. Colin, J. L. Dirion, P. Arlabosse and S. Salvador, Fuel, 197, $232 \quad$ (2017), http://dx.doi.org/10.1016/j.fuel.2017.02.028

36 B. Gullón, R. Yáñez, J. L. Alonso and J. C. Parajó, Bioresour. Technol., 101, $6676 \quad$ (2010), http://dx.doi.org/10.1016/j.biortech.2010.03.080

37 K. Candelier, M. Chaouch, S. Dumaray, A. Pétrissans, M. Pétrissans et al., J. Anal. Appl. Pyrol., 92, $376 \quad$ (2011), https://doi.org/10.1016/j.jaap.2011.07.010
38 P. H. G. Cademartori, E. Schneid, D. A. Gatto, R. Beltrame and D. M. Stangerlin, Mater. Res., 15, 922 (2012), https://doi.org/10.1590/S151614392012005000136

39 P. H. G. Cademartori, P. S. B. Santos, L. Serrano, J. Labidi and D. A. Gatto, Ind. Crop. Prod., 45, 360 (2013), http://dx.doi.org/10.1016/j.indcrop.2012.12.048

40 A. Aytin, S. Korkut, O. Ünsal and N. Çakıcıer, BioResources, 10, $2083 \quad$ (2015), https://bioresources.cnr.ncsu.edu/resources/the-effectsof-heat-treatment-with-the-thermowood-method-onthe-equilibrium-moisture-content-and-dimensionalstability-of-wild-cherry-wood/

${ }^{41}$ V. Nasir, S. Nourian, S. Avramidis and J. Cool, Holzforschung, $\quad \mathbf{7 3}, \quad 381 \quad$ (2019), https://doi.org/10.1515/hf-2018-0146

42 A. F. Dias Júnior, L. P. Pirola, S. Takeshita, A. Q. Lana, J. O. Brito et al., Cerne, 22, 423 (2016), https://doi.org/10.1590/01047760201622032175

${ }_{43}$ A. G. Carvalho, A. J. V. Zanuncio, B. R. Vital, A. C. O. Carneiro, C. M. S. da Silva et al., Eur. J. Wood. Wood. Prod., 76, $155 \quad$ (2018), http://dx.doi.org/10.1007/s00107-017-1234-3

44 H. S. Kol, G. Özbay and S. Altun, BioResources, 4, 1545 (2009),

https://ojs.cnr.ncsu.edu/index.php/BioRes/article/view/ BioRes_04_4_1545_SahinKol_OA_Shear_Stress_Hea t_Treat_Tali_Adhesives

${ }^{4} \overline{5}$ T. H. V. Nguyen. T. T. Nguyen, J. Xiaodi, V. D. Nguyen and G. Minghui, Eur. J. Wood Wood Prod., 76, 1697 (2018), https://doi.org/10.1007/s00107-0181351-7

46 M. Hakkou, M. Pétrissans, A. Zoulalian and P. Gérardin, Polym. Degrad. Stabil., 89, 1 (2005), https://doi.org/10.1016/j.polymdegradstab.2004.10.017 47 D. Chu, L. Xue, Y. Zhang, L. Kang and J. Mu, BioResources, 11, $6948 \quad$ (2016), https://bioresources.cnr.ncsu.edu/resources/surfacecharacteristics-of-poplar-wood-with-high-temperatureheat-treatment-wettability-and-surface-brittleness/ 48 E. Güntekin, T. Y. Aydin and B. Üner, Drv. Ind., 68 , 99

(2017),

https://hrcak.srce.hr/index.php?show=clanak\&id_clana $\mathrm{k}$ jezik=270498

${ }^{49}$ M. Gaff, F. Kačík and M. Gašparík, Compos. Struct., $\quad$ 216, $\quad 80 \quad$ (2019), https://doi.org/10.1016/j.compstruct.2019.02.091

50 American Society for Testing and Materials, ASTM D 3110 Specification for Adhesives Used in Laminate Joints for Nonstructural Glued Lumber Products, 1995 